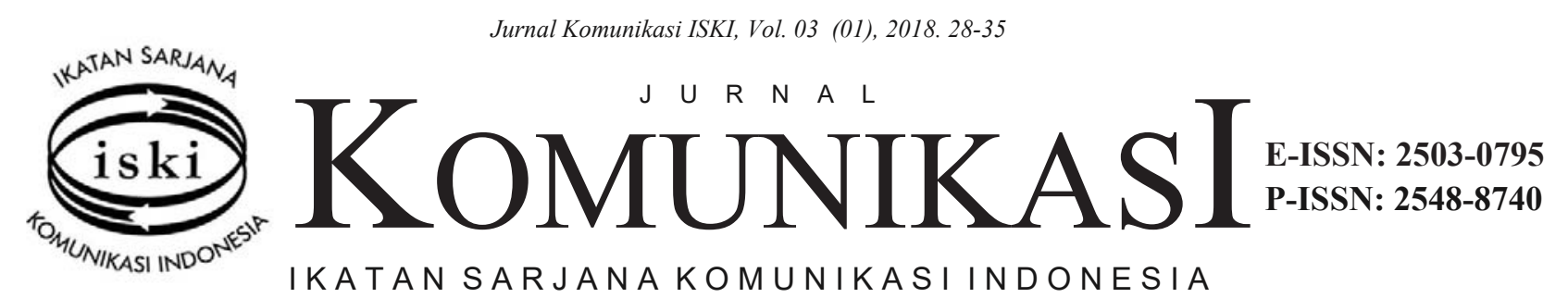

\title{
Binary Opposition in Narrations of "Native" in Social Media
}

\author{
http://dx.doi.org/10.25008/jkiski.v3i1.146 \\ Puspitasari \\ Universitas Indonesia \\ Jl. Salemba Raya No. 4, Jakarta 10430 - Indonesia \\ mipuspita@gmail.com
}

\begin{abstract}
The "native" or pribumi term as a narrative emerged into the public sphere raises questions since October 16, 2017 , whether the term is merely a conversation on the surface or more deeply describes the narrative representing the socio-cultural aspect of Indonesian society. The study conducted uses twitter as a locus of observation within the period of November 8-16, 2017. Based on the idea that a social text reflects a narrative building constructed socio-cultural and leaves a long history trail. Preceding findings indicate that Indonesian society has a historical heritage of Dutch colonialism on native and non-native (Chinese/Tionghoa). The "native" narratives of the present are not only built on the issue of social inequalities between native versus Chinese, but rather show imaginations about the influence of the Chinese group's economic resources on power. The narrative does not only touch on the economic and political aspects, but also the religions which historically and potentially becomes a conflict played by interest groups in the coming 2018 elections and the 2019 presidential election. Suggestions for anticipating vulnerabilities are to conduct media literacy programs involving multiple stakeholders, both governments and civil society, as well as scholars.
\end{abstract}

Keywords: Native, Levi-Strauss narrative analysis, Binary opposition, Social media, Social conflict

\begin{abstract}
Abstrak
Istilah pribumi sejak 16 Oktober 2017 muncul ke ruang publik dan memunculkan pertanyaan, apakah istilah itu hanya menjadi percakapan di permukaan atau menggambarkan narasi yang merepresentasikan aspek sosiokultural dalam masyarakat Indonesia. Penelitian dilakukan dengan menggunakan media sosial sebagai lokus amatan dalam kurun waktu 8-16 November 2017. Didasari pemikiran bahwa sebuah teks sosial merefleksikan sebuah bangunan narasi yang dikonstruksikan secara sosio-kulural dan meninggalkan jejak sejarah panjang. Temuan awal menunjukkan bahwa masyarakat Indonesia secara historis memiliki warisan sejarah kolonialisme Belanda tentang pribumi dan nonpribumi. Narasi "pribumi" pada masa sekarang tidak hanya dibangun berdasarkan isu kesenjangan sosial antara pribumi versus nonpribumi, melainkan menunjukkan imajinasi tentang pengaruh sumber daya ekonomi kelompok Tionghoa pada kekuasaan. Narasi tidak hanya menyinggung aspek ekonomi dan politik, melainkan juga agama, secara historis berpotensi menjadi konflik yang dimainkan kelompok kepentingan terutema menjelang Pilkada 2018 dan Pilpres 2019. Saran untuk mengantisipasi kerawanan adalah dengan melakukan program literasi media yang melibatkan beragam pemangku kepentingan, baik pemerintah maupun masyarakat sipil, dan para akademisi.
\end{abstract}

Kata kunci: Pribumi, Analisis naratif Levi-Strauss, Oposisi biner, Media sosial, Konflik sosial

Copyright @ 2017 Ikatan Sarjana Komunikasi Indonesia. All rights reserved 


\section{Introduction}

Currently developing situations that interpret reality into binary opposition: or A or B. Beginning with the elections of DKI 2017, bringing the people of Jakarta, and even (parts of) Indonesia into a categorical narrative.

Situation of narrative expression characterized by polarization-based is getting pushed in the community, especially after social media becomes a revolutionary medium that fills the role of public participation as a rival or complement and the original information is monopoly held by conventional media, such as newspapers, magazines and television.

Referring to history, the presence of social media was originally preceded by the presence of internet technology in Indonesia, which in the mid1990s began with e-mail and the establishment of mailing lists. In the research of David T. Hill and Krishna Sen (2005) the internet contributed to the democratization process especially in promoting an era of political openness during the Soeharto era gripped by authoritarianism. The authoritarian style itself appears in a press system that embraces a principle of freedom and responsibility which indicates a repression of government, as Daniel Dhakidae put it in his dissertation (1991).

The presence of the internet in Indonesia since its inception led to a kind of atmosphere of openness and euphoria of democracy, so it is not surprising that then the information technology gives an advance to the social media platform presenting similar consequences, namely the atmosphere of openness, the freedom as the essence of democracy.

The two leaders of this country, Susilo Bambang Yudhoyono and Joko Widodo are aware of the changing flow of freedom of information in accordance with the power of information technology, thus utilizing the existence of this technology. They benefit from social media to gain political support from the public. Yudhoyono and Widodo both noted that the recent atmosphere shows the face of inhospitable social media, even raising the idea that because of social media, there is a surplus of freedom and compliance deficit (2014), and Widodo formulated that what is happening today is democracy overflow (February 2017).

What is the flow of freedom of information in the period marked by the Post Truth phenomenon? One of the highlights is the strong tendency in the community that builds in-group and out-group atmosphere. A number of social attributes are attached to the group and reinforce social identity in groups, those who have attributes that have attachment, either in a sense of belonging or affiliation with a particular culture (or sub-culture) (Ting-Toomey and Chung, 2011)

Thus, they will have strong in-group feelings through the narrative sharing process. The process of sharing narratives is symbolically affiliated with the same values. And those who do not have a similar symbolic affiliation will be categorized as out-group. So the narratives with the binary opposition in social media actually represent the process of in-grouping and out-grouping in society.

In the 2017 Jakarta Regional Head election, the tendency of favoring one of the candidates strengthen, each group raises symbols that indicate favorability. Although not all members of the public are included in the binary categorization process, the tendency of symbolic value references continues arbitrarily, and is accepted as a norm.

Post Jakarta Election 2017, the binary narrative continues, although not as harshly as election. Governor of DKI period 2017-2022, Anies Baswedan in his inaugural speech as governor raised the discourse that became problematic and controversial, namely "native", or "pribumi"

Although there are arguments of some parties that native discourse does not need to be linked diametrically with non-native like Chinese, in fact, the social reality of this narrative in society points to different things.

Throughout the observation of the researchers, up to one month after the speech, which is November 16, 2017, the discourse on "native" is still strong in social media. Even some twitter accounts give account names using the word "native", such as @pribumi Independen, @Lembah pribumi,@bahasa Pribumi, @Pribumi hebat.

Naming the account using "native" term is interesting phenomena where the narrative appears diverse having satirical tone to criticize and exclude the other, even a proportionate, not even a little rough and loaded primordial. The visible picture in these accounts is a picture of disintegration within Indonesian society. And these are narrative forms that threaten the national resilience of our nation.

Referred to Levi-Strauss, humans have basic skills which are inherited genetically especially in the ability to structure (structuring) on the symptoms that it faces (Eriyanto, 2013: 165). The structure present in the narrative by Levi-Strauss is referred to as surface structures. The surface structure is a structure realized by its speakers describing 
something that exists in the deep structure. The inner structure is the one behind the narratives or stories.

Levi-Strauss explained that the human ability to structure the narrative is genetic -it feels like re-reading Kahin and Parakitri explaining that the distinction of treatment in classes (formed by the Dutch East Indies colonial government) has led the society to put other humans in different groups as others who have tendencies to discriminate (Puspitasari, 2012: 4).

Thus the entire narrative that emerges today in fact is a part of the process of social inheritance, or social construction perpetuated by existing social institutions, whether the institutions of families, schools, colleges, religions, politics and economics, consciously and collectively. Based on this perspectives meant that consuming or reading the message in twitter accounts is the same as reading the social construction process that takes place. Through the twitter account, people enter the social construction process that occurs, and be involved in the process of externalization of the author of the account and they will try to internalize the idea to its follower. People consume and reproduce the social reality.

Why are tweets in social media considered as narratives? The narration according to Herman and Vervaeck in Eriyanto (2013: 2) has the first characteristic, the existence of a series of events. Naming accounts "native" emerged after the native discourse echoed by Baswedan. The "native" narrative then continues in social media.

The second characteristic is that the sequence of events is not a random event, but follows certain logic, both in terms of causality and chronological, thus indicating a logical relationship (Eriyanto, 2013: 2). And third, in the narrative there is a process of selecting and eliminating certain parts of the event as seen in the process of composing a sentence that specifically selects a particular issue to develop and eliminates a particular part, as part of a binary opposition-building strategy according to Levi-Strauss.

As a social text, the term of "native" is not neutral since its birth in Indonesia, even in Southeast Asia. As noted in the study of Haryanto (2015), Chinese community group have relatively more legal protection than native groups (or at the time referred to as the Bumiputera) and thus the legal system is integrated with a civil law system. Social class divisions consisting of three groups of people create these groupings divided society which affect the interaction between them, especially the Dutch which gives greater access to the Chinese community groups in the fields of education and economic (Haryanto, 2015: 1-2).

The diametrical positions marked by prejudice which exist from the time of Dutch colonialism and show an unfinished position, and one of them was strengthened in the May 1998 Tragedy. The widespread mass rage was triggered by Native versus Chinese meaning which resulted a number of shop, Chinese descendants burned, attacked and even the alleged raping a number of Chinese women. In that event, a number of shops and houses felt the need to mark on the walls of houses and shops with pribumi (native) words to be safe from mass amok attacks. Since that time, the Chinese term has become traumatic and has been replaced by Tionghoa, with the aim of eliminating historical trauma from Chinese groups and negating negative prejudices through naming that are expected to have positive connotations and opening new pages in the process of social interaction.

Reflecting on the narrative history of the "native" who, in some ways, was diametrically opposed to the Chinese (and now: Tionghoa), after 16 October 2017 was resurrected in the face of social media in Indonesia.

From the above explanation identified a number of issues in accordance with the developments in technology and the dynamics of society, namely: communication technology revolution, the consequences on the free flow of information.

Freedom of information flows into a necessity that represents binary opposition. Binary opposition becomes a reality that is presented in social media.

Binary opposition construction represents an inner structure that historically shows the face of deep categorization and the potential for directing national divisions. Binary opposition constructions built since October 16, 2017, unconsciously stretched in the space of social media and diametrically to set an unbalanced binary relationship.

This study aims to determine: (1) Knowledge, meaning and value about "native" texts produced and disseminated in society? (2) The narrative about the social and political world behind the text of the "natives", and (3) Overview of the latent meaning of text in twitter account. 
Theoretical Framework

\section{Concept of Diametral prejudice: Native} versus Chinese

Haryanto explained that the division of society was into three groups of society during the Dutch East Indies colonial make the society and racial prejudice divide. The grouping, either directly or indirectly, influenced the interaction between the two, moreover at that time the Dutch gave more access and granted privileges to Chinese citizens in education and economics (Haryanto, 2015: 1-2)

The indifference of "native" Indonesians to Chinese community has been going on for a long time, especially at the time of the Chinese War on Java. Although the war was in fact an opposition given by Chinese descendants to the Dutch, as the Dutch expelled unilaterally against the Chinese descendants, during the war, Sunan Pakubuwana II intended to exploit the moment to expel the Netherlands by sending reinforcements to the descendants China, but the reinforcements were defeated and the Chinese was despair to defeat and turned against Sunan Pakubuwana II -the hatred became to grow rapidly as the Chinese descendants got the monopoly rights of the opium trade on the North Coast of Java (Maulani in Haryanto, 2015).

Since then, feelings of dislike for Chinese have been preserved to produce actions that seek to destroy Chinese descendants, one of which is the Diponegoro War (1825-1830). Maulani in Haryanto (2015: 2) reveals that the Diponegoro War was not only limited as a fight against the Dutch, but was an opportunity that the Javanese did not wasted away from their hatred of Chinese, during the five years of war, and the slaughter of Chinese occurred in Mataram.

And since then the stereotypes attached to Chinese are opportunistic, justifying any means to pursue wealth, the oppressive group of native people attached and inherited historically in the Javanese social construction process (Haryanto, 2013: 2-3).

Coppel explained that in the lead up to the G30S/PKI event, there was a Voice of Islam mentioning that Prime Minister Djuanda died of toxic Chinese wine (Haryanto, 2015: 2). Sentiments against Chinese descendants continued throughout the New Order government, where there was a ban on activities related to Chinese tradition, including the ban on the use of Chinese in Indonesia. In addition, Chinese are not allowed to engage in politics, the only area given by the New Order government is the economy (Sa'dun in Haryanto,
2015: 2). Not only is it mentioned that China is perceived as a communist henchman.

The variety of stereotypes produces a negative prejudice to the historically inherited group of Chinese emerging and manifesting to this day, as seen in the narrative that appears in a number of twitter accounts.

In James Hawdon research, Laura E. Agnich, and John Ryan of Virginia Tech on "Media Framing of a Tragedy: A Content Analysis of Print Media Coverage of the Virginia Tech Tragedy" (2013) found how print media in the United States framed the news about the Virginia Tech tragedy and how it affected the Virgnia Tech community.

Research holds to the basic assumption that mass media can accelerate or even exacerbate the process of healing the community for grief due to the tragedy that occurred. To answer the formulation of the problem, the three researchers from Virginia Tech analyzed all the coverage of the Virginia Tech tragedy on the New York Times, the Washington Post, the Chicago Tribune, the Los Angeles Times, the Wall Street Journal, and the Roanoke Times, between April 16 and June 20,

\section{Social Construction in News}

Gaye Tuchman, in Severin and Tankard (2005: 400), explained that news is a construction of social reality. The act of making the news is the act of constructing the reality itself. News becomes an ally for legitimate institutions and that news also legitimizes the status quo.

Narratives that appear in social media become a tool to build conformity in the process of building (politics) identity through in-grouping. Through the narration, comments and share and high number of followers become a tool to legitimize the "truth voice" by negating others. Thus posting such messages becomes a tool of legitimizing the status quo into a socially distributed information resource via viral on social media.

Alex Sobur (2001: 166-167) mentioned that basically in reconstructing a reality, journalists tend to incorporate their crystallized experience and knowledge into a schemata of interpretation, similarly done by the netizen who reveals a narrative based on already crystallized knowledge.

Sobur then argued (2001: 167) that with this scheme, journalists tend to limit or select sources of news, interpret news sources' comments, and give different portions of the interpretations or perspectives that appear in media discourse. Netizen also distributes narratives through the process of 
information selection and interpretation according to the interpretation scheme it possesses.

\section{Construction of Meanings in a Context of Narrative}

Referring to Levi-Strauss who says that humans have a genetically inherited basic ability, especially in the ability to structure (structuring) the symptoms it faces (Eriyanto, 2013: 165). The existing structure of the narrative in social media, for example, is mentioned by Levi-Strauss surface structures. This surface structure itself, according to Levi Strauss is a structure recognized by the speaker describing something that is in the deep structure (deep structure). The inner structure itself is the one behind the narratives or stories. And further, the relations that exist in the structure can be simplified into opposition in pairs or binary opposition.

Binary opposition is an important aspect which is considered to reveal how people think, and at the same time the production of meaning and understanding of reality (Culler, in Eriyanto, 2013: 166).

\section{Material and Methodology}

This study is qualitative which emphasizes on how the reality under study is comprehensively understood. This qualitative study does not depart from attempting to believe the "truth" in the studied narrative because it is based on the understanding that truth has multiple versions to express itself (Stake in Creswell, 2015: 71). As Creswell attempted to have resonance in the study and becomes an accurate reflection of the narratives conveyed by the parties observed in this study (2015: 71), the researchers followed the process in validation including triangulation of data with some credible references (2015: 71)

One of the ways in this study is to focus on a textual theme of "native" as a basis for seeing how a binary opposition image is formed in society as represented in social media accounts (Creswell, 2015: 72).

Data are obtained from two primary and secondary data sources. The primary data source used is a twit post in a social media account that uses "native" as a keyword. The observation period is limited to November 8-16, 2017. The timing of the election spans controversy in the conventional media space, beginning with Anies Baswedan's speech with the theme "Native" on October 16, which began to disappear from the conventional media room in early November 2017. But unlike reality in the conventional media space, "native" narratives still appear even until November 16 of which it is the final period of data input for the purposes of writing this article.

Secondary data is obtained through crossdisciplinary literature studies, sociology, anthropology, communications related to ethnicity, prejudice and cross-cultural communication and social media, as well as national resilience perspectives.

The data analysis technique presents a narrative analysis referring to the binary opposition concept of Levi-Strauss. Levi-Strauss explains that humans have a genetically inherited basic ability, especially in the ability to structure (structuring) the symptoms it faces (Eriyanto, 2013: 165). The structures present in the narrative in social media for example are surface structures. The surface structure is a structure that the speaker recognizes, describing reveal something that exists in the deep structure. The inner structure itself is the one behind the narratives or stories. Furthermore, the relations to the inner structure can be simplified into a paired (binary) opposition.

Binary opposition is an important aspect to reveal how humans think and simultaneously produces meaning and understand reality (Culler, in Eriyanto, 2013: 166).

It is said that a narrative always has a binary opposition seen from a series and relations among words, sentences, images and scenes of a narrative (Eriyanto 2013: 171). The meaning of a narrative is not seen on an independent element rather than the relation between the elements. By making relationships between the elements of a story, the meaning of a story can be seen, known and understood. From there it will be seen that the author has his own logic, thought and reason (Eriyanto, 2013: 171)

There are three steps to find the binary opposition of a narrative according to Eriyanto (2013: 171-172). The first is to search for my-theme which is the smallest element of the narrative that can be a sentence, a scene, or a series of sentences. The next stage is to find a relationship between mythemes. A narrative gives the reader a grid that can only be understood by looking at the rules which underlie its construction. What then became the basis of his construction, that is his views on the world.

In the last section is to arrange my-theme which is syntagmatic and paradigmatic. Arranging my-theme in syntagmatic is composing words, sentences and drawings in sequence. While 
preparing the paradigmatic mytheme is to place mytheme according to its position and paradigm in a unity of meaning. The circuit between syntagmatic and paradigmatic elements form a collection of relations. After that the patterns formed from syntagmatic and paradigmatic relations are interpreted by the researchers.

\section{Result and Discussion}

The term "native" polemic has been rolling since Anies Baswedan as the Governor of DKI Jakarta was elected to deliver its first speech on October 16, 2017. Although the term Natives is only a small part of the whole speech that brings up the long history of the Republic of Indonesia in Jakarta, it has sparked post-speech controversy. As quoted by Kompas, Anies said that every corner in Jakarta holds history, and the end of colonialism that had happened in Jakarta for hundreds of years should be a momentum for the natives to do development and to be a good host, "In the past we all natives were oppressed and defeated (colonized ). Now it's free, it's time we host in our own country".

Some refer to the legality aspect of Law No. 40 of 2008 on the Elimination of Racial and Ethnic Discrimination, and Presidential Instruction No. 26/1998 on Termination of the Terms of Native and Non-Individuals in All Formulation and Implementation of Program Policies, Program Planning, or Implementation of Governance Activities. Others refer to the reasons for respecting and respecting diversity in Indonesia.

Some see the use of the native term as valid, since both President Joko Widodo and Vice President Jusuf Kalla have used the same term, but it is not questioned as in the case of Baswedan. The controversy culminated in social media in the days after the Speech was delivered to public.

Baswedan explained later in his defense, that the use of the term "native" or "pribumi" is in the context of Dutch colonialism in Indonesia. He does not refer to the use of the word in the present era.

A later phenomenon that can not be prevented is that the narrative of the "native" continues to appear in the public sphere and undergoes the process of being produced, consumed and reproduced.

Baswedan is in the context of performing reproductive functions, and as a public official, the reproductive function undergoes an amplication that results in a narrative being firmly entrenched in the public mind.
The narrative that appears in social media is diverse, from which the natives associate it as a cultural identity opposite the Chinese pole to the one that puts the natives as an identity projected into the political-economic space by paralleling the idea of non-native with Chinese and Chinese. Some based their narratives on negative prejudices against ethnic Chinese and placed the native diametral in a positive and even ethnocentric position.

Some accounts represent several very diverse groups, ranging from naming accounts as "Natives" such as @Lembah Pribumi, @BahasaPribumi, and so on. Observation of 57 tweets were in the period from 8 to 16 November 2017.

Some tweets picked up anti-Chinese sentiments by placing harsh speeches, "aseng" and "sengkek". Not only that, the other mention is "Chinese dirty" and "dirty Chinese", even placed in the context of LGBT, as seen in the following text:

"... The HIV virus is coming from ??

Most LGBT people from where ??

vigilant HIV / AID virus spreading from Chinese people JOROK (dirty) "

Another passage mentions the linearity with Baswedan's idea of the issue of colonization, stating, "The colonialism of henchmen (sic!) ..."

Then there is the theme that deals with the stereotype of Chinese groups as businesspeople, by building a narrative on "Chinese agents" (China). The narrative is built by developing the imagination of industry discrimination and appropriation to nonnative, non-Muslim people, as seen in the following tweets,

"Just check the TV legal body bewok, meet the majority shareholder PT subsidiary J1 conglomeration group"

JR is meant here is James Riyadi, business owner in the conglomerate group Lippo Group. Explained further in the next narration, "Check the directors, just the native bewok, other Chinese. Check (the chief of) editors: all non-Muslims. "

Other narratives put the natives as the poor, the destitute, and became victims of the occupation of Chinese groups and awaited prey by the authorities.

A number of such data show a number of binary oppositions in the narration in the social media space as shown in the following table: 
Table 1. Binary opposition "Natives" in Twitter, 8-16 November 2017

\begin{tabular}{|l|l|}
\hline NATIVE & CHINESE \\
\hline victim & Predator \\
\hline Muslim & Non-Muslim \\
\hline People & Ruler's arms \\
\hline Poor & Rich \\
\hline Weak & $\begin{array}{l}\text { Forceful (because of the } \\
\text { economic capital owned) } \\
\text { Wide access (then } \\
\text { powerful) }\end{array}$ \\
\hline Marginalized, isolated & Powerful \\
\hline Victim of development & $\begin{array}{l}\text { China's economic } \\
\text { expansion agent }\end{array}$ \\
\hline
\end{tabular}

As seen above, at one point the poles have placed the "native" in a weak, poor, isolated and victimized category. One of the consequences of a victim's position is the limited access and victimization in development process. At this point, the government of Joko Widodo was identified by the first pole as a party involved in cooperation with non-native parties, thus placing native groups as oppressed parties.

While Chinese groups in binary opposition are placed in positions of power in terms of capital resources allowing them freedom of access to strategic positions. Because they have the power of the resources they believe to make a systematic effort to prey the native groups.

This narrative builds the narrative about "being a strong native". Moreover, the narrative then comes to the real threat of an interest in the expansion of the Chinese economy which has implications for the mobilization of foreign workers from China flowing into Indonesia both legally and illegally, then could be potentially a real threat to the sustainability of native groups in the work field.

The mechanism of internalization in the social construction process that occurs through Native versus Chinese narratives rests on the economic base has the potential to build community disintegration through the reinforcement of prejudices that have been sown little by little in the construction of meaning relations between native and Chinese ethnic groups in Indonesia.

The alternative narratives that are positively native and Chinese positions nearly drowned in the social media space. Mohamad Guntur Romli, a young activist activist with his social media account conveyed an alternative narrative and was immediately hit with an issue that placed himself as a representation of out-group in the collective realm of social media.

The narrative of native puts relationships in an imbalanced or in perspective negating the positive value of Chinese groups increasingly gaining wider space and being left out. Although it must be admitted that the follower of this group is not large, but it should be noted that the process of internalization continues till the time will shift the narrative of natives and in time will find its own way to reappear with pressure that may be the same, or perhaps also different.

What is also interesting is that in the narrative about the native text appears widening out of the usual binary opposition -- diametrically putting the natives in the category of Muslims and Chinese as Non-Muslims. Once the Native texts appear, which operate in the domain of ethnicity, are juxtaposed with Muslims and non-Muslims operating in the religious domain, this narrative contains new potential dangers. The issue of religion itself is in many cases an easy issue for conflict. It is also interesting how conventional mass media is highlighted as well as being mentioned as being affiliated with Chinese as well as non-Muslim.

Highlight on the involvement of conventional mass media owners with non-Muslim entrepreneurs is not only discussed in co-operation between the two parties, but also implies a social texts that the involvement of Chinese businessmen has an impact on the organization of the media. Speakers convey narratives that stem from the agenda setting concept wherein the media agenda is most likely to be controlled by the interests of the owner of capital (Shoemaker and Reese, 1996).

The narrative of the attached religion shows the structure of public awareness of native and Chinese people constructed in binary--placing Chinese weakly in socio-cultural and political positions with multiple vulnerabilities. Vulnerability stems from a narrative that culturally puts religion, in this case non-Muslims is a narrative that is also interpreted negatively. It is double conceivable where Chinese and non-Muslim narratives are linked in order to have a strong echo in constructing an outgroup. 


\section{Conclusions}

The structure of Indonesian society has historically been built on the socio-cultural vulnerability as a historical heritage of Dutch colonialism, the narrative of native and non-native, or in this case specifically pointed at Chinese that can be seen as a narrative and also undergoes historical construction process. The narrative of the native people built in the social media spaces shows the traces of internalization, objectivity and externalization that have taken place over the long period of the nation's history.

The rise of the native texts as presented by Baswedan, is a "historical accident," which Mahfud $\mathrm{MD}$ and Baswedan argue in his defense, arises not from an intention to discriminate. But the social text revived the narrative of native versus Chinese that has been constructed over a long period. The narrative not only implies the issue of social inequalities between native versus Chinese, and even shows the imagination about the influence of the Chinese group's economic resources on the power and how the media industry in running the media practices accused of indulging in the interests of Chinese groups.

The narrative does not only touch on the economic and political aspects, but also the religious aspect, which is known historically has the vulnerability to explode as a potential conflict that can be a playable instrument in the coming 2018 elections and the 2019 presidential election.

Media literacy becomes a need to be disseminated into the public sphere through social media displaying the rich history of Indonesian nations that is colored by the harmony and openness of the fathers of the nation and those who serve to encourage Indonesia to be a just nation and to uphold the values of diversity in order to achieve single based on Pancasila values.

The process of media literacy is a shared responsibility between social media activists, academics, and government with all apparatus working in the realm of public communication such as Minister of Communication and Information and KPI as well as civil society groups.

\section{References:}

Creswell, J. 2015. Penelitian Kualitatif dan Desain Riset. Yogyakarta: Pustaka Pelajar

Dhakidae, D. 1991. "The State, the Rise of Capital, and the Fall of Political Journalism, Political Economy of Indonesian News Industry", Dissertation pada Cornell University, di Department of Goverment, Ilmu Politik, Ithaca, New York

Eriyanto, 2013. Analisis Naratif: Dasardasar dan Penerapannya dalam Analisis Teks Berita Media. Jakarta: Kencana Prenada Media Group.

Haryanto, R, 2015. "Analisa Wacana Anti Cina dalam Pemberitaan Harian Kompas dan Republika Menjelang Kerusuhan Mei 1998". Thesis on Universitas Indonesia

Hawdon, J, Agnich, LE dan Ryan J. 2013 "Media Framing of a Tragedy: A Content Analysis of Print Media Coverage of the Virginia Tech Tragedy" https://www.researchgate.net/.../268515906_Media Framing_of_a_Tragedy_A_Cont...

Hill, D dan Sen, K. 2005. The Internet in Indonesia's New Democracy. London: Routledge.

Puspitasari, 2012. "Kontestasi Pemaknaan Teks Pluralisme dalam Arena Media Sosial". Dissertation on Universitas Indonesia.

-Severin, WJ dan Tankard, JW. 2005. Teori Komunikasi. Jakarta: Jakarta

Shoemaker, P dan Reese, S (1996). Mediating the Message: Theories of Influences on Mass Media Content. USA: Longman

Sobur, A, 2001. Analisis Teks Media: suatu Pengantar untuk Analisis Wacana, Analisis Semiotika dan Analisis Framing. Bandung: PT Remaja Rosda Karya

Ting-Toomey, S dan Chung, L. 2011. Understanding Intercultural Communication. USA: Oxford University Press 